\title{
EKSTRAKSI UNSUR HARA DARI RUMPUT LAUT Sargassum sp.
}

\section{Nutrient Extraction from Seaweed Sargassum sp.}

\author{
Jamal Basmal ${ }^{*}$, Radian Saputra ${ }^{2}$, Rahman Karnila², dan Tjipto Leksono ${ }^{2}$ \\ 'Balai Besar Riset Pengolahan Produk dan Bioteknologi Kelautan dan Perikanan, Badan Riset dan Sumber Daya Manusia \\ Kelautan dan Perikanan, JI. KS.Tubun Petamburan VI, Slipi, Jakarta, Indonesia \\ ${ }^{2}$ Universitas Riau, Kampus Bina Widya Km 12,5 Simpang Baru Pekanbaru, Indonesia \\ ${ }^{*}$ Korespondensi Penulis:
}

Diterima: 1 Agustus 2018; Direvisi: 31 Januari 2019; Disetujui: 27 Mei 2019

\begin{abstract}
ABSTRAK
Penelitian pengaruh suhu dan waktu esktraksi terhadap jumlah unsur hara makro yang ke luar dari rumput laut Sargassum sp. telah dilakukan dengan cara merendam rumput laut Sargassum sp. dalam larutan $\mathrm{KOH} 0,3 \%$ selama 5 hari, selanjutnya rumput laut diberi perlakuan waktu dan suhu ekstraksi yang berbeda yakni $T_{1}$ (120 menit); $T_{2}$ (180 menit); dan $T_{3}$ (240 menit), dengan suhu ekstraksi yaitu $\mathrm{S}_{1}\left(60^{\circ} \mathrm{C}\right) ; \mathrm{S}_{2}\left(70^{\circ} \mathrm{C}\right)$; dan $\mathrm{S}_{3}\left(80^{\circ} \mathrm{C}\right)$. Tujuan penelitian ini adalah untuk mendapatkan unsur hara makro dan karakteristik fisik dan mikrobiologi yang optimal dari ekstrak cair rumput laut Sargassum sp. Hasil penelitian menunjukkan bahwa perlakuan suhu dan waktu ekstraksi berpengaruh signifikan terhadap jumlah unsur hara, viskositas, angka lempeng total (ALT), fosfat, $\mathrm{C}_{\text {Organik }}$, dan EC dari cairan ekstraksi rumput laut Sargassum sp., namun tidak berpengaruh terhadap $\mathrm{pH}$, kadar nitrogen, dan kadar kaliumnya. Hasil ekstraksi terbaik ditemukan pada kombinasi perlakuan lama waktu 240 menit (4 jam) dengan suhu $80{ }^{\circ} \mathrm{C}$, yaitu dengan jumlah larutan ekstrak yang mengandung unsur hara sebesar 97,5\%; pH 9; viskositas 3,07 cPs; ALT 2,5 x 103 Cfu/mL; nitrogen1,64\%; fosfat 197,7 ppm; kalium 205,54 ppm; $\mathrm{C}_{\text {Organik }} 0,55$ $\%$; EC $3,52 \mathrm{mS} / \mathrm{cm}$ dan $\mathrm{C} / \mathrm{N}$ rasio $0,34 \%$.
\end{abstract}

KATA KUNCI : rumput laut, Sargassum sp., ekstrak cair, waktu ekstraksi, unsur hara

\section{ABSTRACT}

Nutrient extraction from seaweed (Sargassum sp.) was done by soaking the seaweed in a $0.3 \% \mathrm{KOH}$ solution during 5 days. Furthermore, the seaweed was treated at various extraction times $\left(T_{1}=120 \mathrm{~min} ; T_{2}=180 \mathrm{~min}\right.$; and $\left.T_{3}=240 \mathrm{~min}\right)$ and temperatures $\left(S_{1}=60^{\circ} \mathrm{C} ; \mathrm{S}_{2}=70^{\circ} \mathrm{C}\right.$; and $S_{3}=80^{\circ} \mathrm{C}$ ). This study aimed to obtain optimum macro nutrients value and the physical and microbiological characteristics of the liquid extracted from seaweed Sargassum sp. The results showed that the variation of temperature and extraction time was affected significantly on the yield, viscosity, total plate count (TPC), phosphorus, $C_{\text {organic }}$ and EC of the extracted liquid from seaweed Sargassum sp., but it did not affect the $\mathrm{pH}$, nitrogen and potassium contents. The best result was found in combination of 240 min extraction time at $80^{\circ} \mathrm{C}$ temperature with the yield of $97.5 \% ; \mathrm{pH}$ 9; viscosity $3.07 \mathrm{cPs}$; ALT $2.5 \times 10^{3} \mathrm{Cfu} / \mathrm{mL}$; nitrogen 1.64\%; phospat 197.7 ppm; potassium 205.54 ppm; $C_{\text {organic }} 0.55 \% ; E C 3.52 \mathrm{mS} / \mathrm{cm}$ and $\mathrm{C} / \mathrm{N}$ ratio $0.34 \%$

KEYWORDS: seaweed, Sargassum sp., liquid extract, extraction time, nutrient

\section{PENDAHULUAN}

Praktek pertanian modern yang berkelanjutan dan ramah lingkungan dapat dicapai dengan cara mengaktifkan metabolisme tanaman, untuk meningkatkan produksi tanaman (Compagnon, 1986 dalam Putranto, 2012). Bulgari, Cocetta, Trivellini, Vernieri, dan Ferrante (2015) menyatakan biostimulan dari tanaman mengandung berbagai macam senyawa bioaktif yang mampu meningkatkan daya serap nutrisi dan meningkatkan toleransi terhadap tekanan biotik dan abiotik. Zodape (2001) melaporkan biostimulan dari ganggang laut seperti Fucus vesiculata. Furcelaria fastigiata, Hypnea musiformis, Sargassum sp., Ascophylum nodosum (Algifert), Ulva lactuca, Durlillea potatorum, padina, Turbinaria sp., dan Laminaria telah digunakan sejak 40 tahun yang lalu pada berbagai tanaman untuk memacu pertumbuhan dan perkembangan tanaman. Shah, Zodape, Ram Chaudhary, Eswaran, dan Chikara (2013) menyatakan 
pemberian 7,5\% konsentrasi ekstrak cair $K$. alvarezii telah meningkatkan kandungan unsur hara kalium (7,9\%), dan sulfur $(31,8 \%)$ serta dapat meningkatkan produksi biji gandum. Layek et al. (2015) dalam penelitiannya menemukan bahwa pemberian ekstrak cair rumput laut Kappaphycus alvarezii and Gracilaria edulis telah meningkatkan produktivitas rendemen jagung 10,5-13,1\%, karbohidrat $12,3-17,4 \%$ dan kandungan protein $4,8 \%$.

Menurut Muhhamid (2012) dan Handayani, Sutarno dan Setyawan (2004), Sargassum sp. merupakan salah satu genus dari kelompok rumput laut coklat yang terbesar dari famili Sargassaceae dengan komponen utama dalam talus Sargassum sp. adalah holoselulosa (selulosa dan hemiselulosa), lignin, dan alginat. Selain itu talus Sargassum sp. juga mengandung unsur hara (makro dan mikro unsur hara), hormon pemacu tumbuh, protein dan vitamin.

Talus rumput laut Sargasum sp. memiliki ekstrak cair yang mengandung unsur hara mikro dan makro serta hormon pemacu tumbuh (Widanarto, 2013). Hal tersebut diperkuat dengan hasil penelitian Basmal, Kusumawati dan Utomo (2015) yang menemukan dalam ekstrak cair talus rumput laut terkandung zat pemacu tumbuh auksin sebesar $127,48 \mathrm{ppm}$, giberelin 131,11 ppm, sitokinin-kinetin 68,77 ppm, dan sitokininzeatin 82,41 ppm; unsur hara makro kalium (K) sebesar $345,29 \mathrm{mg} / 100 \mathrm{~g}$, nitrogen $(\mathrm{N})$ sebesar $0,78 \%$, fosfor $(P) 55,39 \mathrm{mg} / 100 \mathrm{ml}$, nilai kekentalan $11,5 \mathrm{cPs}$, dan nilai EC $3,3 \mathrm{mS} / \mathrm{cm}$. Menurut Grusak, Broadley, dan White (2001) pupuk cair yang diberikan pada tanaman harus berisi larutan nutrisi yang memenuhi semua unsur hara yang diperlukan olah tanaman. Beberapa unsur hara tersebut di antaranya adalah nitrogen yang berfungsi untuk merangsang pembentukan daun, batang dan cabang, fosfor yang berguna untuk merangsang pertumbuhan akar, batang dan pemasakan biji serta buah, kalium yang berperan membantu dalam menyerap hasil fotosintesis dan menguatkan tanaman,kalsium yang berfungsi mempercepat pertumbuhan akar dan batang, serta mempermudah penyerapan kalium, dan magnesium yang ikut berperan dalam pembentukan klorofil. Selain unsur hara yang tersebut di atas juga perlu diatur nilai electro conductivity $(\mathrm{EC})$ dan nilai keasaman $(\mathrm{pH})$ sesuai dengan kebutuhan masing masing tanaman.

Penyerapan air dan nutrisi oleh tanaman sangat tergantung pada nilai EC dari nutrisi yang disediakan. Metabolisme tanaman di antaranya kecepatan fotosintesis, aktivitas enzim dan potensi penyerapan ion-ion oleh akar sangat dipengaruhi oleh nilai EC dari nutrisi (Anon., 2017d). Tingginya konsentrasi unsur hara yang ada dalam pupuk cair berpengaruh terhadap penyerapan unsur hara pada tanaman, semakin tinggi konsentrasi unsur hara akan semakin lama penggunaan larutan nutrisi dalam sistem tanaman. Nilai EC yang relatif tinggi berakibat tanaman tidak sehat dan tidak dapat menyerap unsur hara dengan baik. Akibatnya terjadi perubahan dalam pembukaan stomata dan pertumbuhan luas daun, yang erat kaitannya dengan efisiensi fotosintesis. (Anon., 2017). Pada tanaman akuaponik dilaporkan nilai EC berkisar antara 0,3 dan $1,1 \mathrm{mS} / \mathrm{cm}$. Beberapa faktor yang mempengaruhi konsentrasi unsur hara makro dan mikro dalam sistem budidaya akuaponik antara lain adalah jenis ikan yang budidayakan di lingkungan tanaman, tahap pertumbuhan, densitas pakan ikan yang digunakan, intensitas pemberian pakan pada ikan, komposisi pakan, dan kemampuan mikroba dalam melarutkan fosfat, melarutkan kalium serta mengubah amonia menjadi nitrat yang dapat langsung diserap oleh tanaman akuaponik. Tidak tersedianya ion $\mathrm{Fe}^{2+}$ dan $\mathrm{K}^{+}$pada sistem akuaponik mengharuskan penambahan ion $\mathrm{K}^{+}$dari larutan $\mathrm{KOH}$ dan $\mathrm{Fe}^{2+}$ dari Fe chelates. Tingkat keasaman larutan berdampak pada daya serap tanaman terhadap nutrisi. Nilai $\mathrm{pH}$ larutan berkaitan erat dengan aktivitas bakteri (nitrifikasi) dalam sistem akuaponik. Firdausi dan Zulaika (2015) melaporkan bahwa bakteri azetobacter dapat mengubah amonia menjadi nitrit dan nitrat dengan $\mathrm{pH}$ optimal sebesar 8,5 , selanjutnya diinformasikan pula bahwa beberapa spesies tanaman akan optimal penyerapan nutrisi pada pH 6,0.

Menurut Hernández-Carmona, McHugh, dan López-Gutiérrez, (1999) faktor yang sangat mempengaruhi jumlah unsur hara mikro \& makro, $\mathrm{C}_{\text {organik }}$, dan nilai kekentalan pada proses ekstraksi zat pemacu tumbuh dari rumput laut Sargassum sp. adalah kualitas dan ukuran bahan yang akan diekstrak, konsentrasi media pelarut, suhu dan waktu ekstraksi. Pendapat ini juga didukung oleh Jayanudin, Lestari dan Nurbayanti (2014) yang mengatakan bahwa faktor yang mempengaruhi kekentalan alginat dari ekstrak Sargassum sp. adalah konsentrasi pelarut, suhu dan waktu ekstraksi. Berdasarkan teori ini maka dilakukan penelitian pengaruh suhu dan waktu ekstraksi unsur hara rumput laut Sargassum sp. dengan tujuan untuk mendapatkan suhu dan waktu optimum terekstraknya unsur hara makro nitrogen, fosfat, kalium, EC dan kekentalan ekstrak cair rumput laut Sargassum sp.

\section{BAHAN DAN METODE}

\section{Bahan dan Alat}

Rumput laut Sargassum sp. merupakan bahan utama yang digunakan dalam penelitian ini,dan diperoleh dari Pantai Binuangeun, Banten. Bahan baku rumput laut Sargassumsp. segar setelah pemanenan 
dicuci dengan air laut kemudian dikeringkan di bawah matahari selama 2 hari, selanjutnya, rumput laut kering dibawa ke laboratorium. Bahan bantu untuk ekstraksi kandungan unsur hara Sargassum sp. menggunakan larutan $\mathrm{KOH} 0,3 \%(\mathrm{v} / \mathrm{v})$.

\section{METODE}

Sargassum sp. kering dicuci bersih dengan air, lalu direndam dalam larutan $\mathrm{KOH} 0,3 \%$ selama 5 hari. Selanjutnya Sargassum sp. ditambah 10 It larutan $\mathrm{KOH} 0,3 \%$, dipanaskan sesuai dengan perlakuan suhu dan lama waktu yang diberikan. Rancangan percobaan yang digunakan pada penelitian ini adalah rancangan acak lengkap (RAL) faktorial dengan dua perlakuan. Perlakuan yang diberikan adalah waktu dan suhu ekstraksi yang terdiri dari 3 taraf dengan 3 kali ulangan yang meliputi waktu ekstraksi (Faktor T): $T_{1}$ (120 menit); $\mathrm{T}_{2}$ (180 menit); $\mathrm{T}_{3}$ (240 menit), sedangkan suhu ekstraksi (Faktor S): $\mathrm{S}_{1}\left(60^{\circ} \mathrm{C}\right) ; \mathrm{S}_{2}\left(70^{\circ} \mathrm{C}\right)$; dan $\mathrm{S}_{3}$ $\left(80^{\circ} \mathrm{C}\right)$ dengan jumlah satuan percobaan pada penelitian ini berjumlah 27 sampel.

Data dianalisis menggunakan analisis sidik ragam (ANOVA) menggunakan aplikasi SAS (Statistical Analysis System) 9.1.3 Portable dan apabila hasil uji Anova menunjukkan pengaruh nyata, akan dilanjutkan dengan uji perbandingan berganda Duncan's multiple range test (DMRT) untuk mengetahui adanya perbedaan masing-masing perlakuan pada tingkat signifikansi $95 \%$.

Proses ekstraksi unsur hara dari dalam Sargassum sp. melibatkan proses pencucian, perendaman, dan ekstraksi. Pada proses pencucian, Sargassum sp. yang telah ditimbang, dicuci bersih dengan air menggunakan mesin pencuci (Mollen) model R1201 Wuxi Hongyuan Leather Machinery Factory, Cina dengan suhu $27^{\circ} \mathrm{C}$, kecepatan $7,2 \mathrm{rpm}$, selama 10 menit dengan perbandingan Sargassum sp. kering : air $=1: 3(\mathrm{~b} / \mathrm{v})$. Selanjutnya rumput laut direndam dalam larutan $\mathrm{KOH} 0,3 \%$ dengan rasio 1:10 (b/v) selama 5 hari. Tujuan perendaman tersebut agar kandungan unsur hara yang ada dalam talus rumput laut dapat dengan mudah ditarik. Setelah itu, dilakukan proses pemasakan pada suhu dan waktu ekstraksi yang telah ditetapkan sebelumnya. Larutan unsur hara yang diperoleh kemudian disaring menggunakan kain blacu dan dihitung sebagai jumlah larutan unsur hara.

Untuk menentukan kandungan unsur hara yang terlarut dalam larutan $\mathrm{KOH} 0,3 \%$ dilakukan analisis kandungan unsur hara yaitu kadar N (SNI. 01-2354.4$2006 \mathrm{BSN}, 2006$ ), serta $\mathrm{P}, \mathrm{K}$, dan $\mathrm{C}_{\text {organik }}$ menggunakan atomic absorption spectrophotometer (AAS) merk Agilent AA400, pH (SNI 19-7030-2004), nilai kekentalan menggunakan Brookfield model LVT serial number 8545043 (brookfiled Enggineering Laboratories dan EC menggunakan EC meter, ALT (Angka Lempengan Total) (SNI 01-2332-3-2006).

\section{HASIL DAN PEMBAHASAN}

\section{Jumlah Larutan Unsur Hara Makro}

Jumlah larutan unsur hara makro (N,P dan K) dari ekstrak rumput laut Sargassum sp. pada penelitian ini berkisar antara $(93 \pm 0,01 \%)-(97,5 \pm 0,01 \%)$ dengan nilai terendah ditemukan pada perlakuan $T_{1} S_{1}\left(T_{1}=\right.$ suhu 120 menit; $S_{1}=60^{\circ} \mathrm{C}$ ) sebesar $93 \%$ dan yang tertinggi ditemukan pada perlakuan $\mathrm{T}_{3} \mathrm{~S}_{3}\left(\mathrm{~T}_{3}=\right.$ waktu ekstraksi 240 menit; $S_{3}=80{ }^{\circ} \mathrm{C}$ ) sebesar $97,5 \%$ (Gambar 1). Berdasarkan hasil rekapitulasi data rataan, ternyata faktor lama waktu ekstraksi $(T)$ dan suhu ekstraksi (S), serta interaksi keduanya (TS) berpengaruh nyata $(p<0,05)$ terhadap jumlah larutan unsur hara dari Sargassum sp. Terbukti bahwa waktu dan suhu ekstraksi berpengaruh terhadap jumlah larutan Sargassum sp. yang dihasilkan. Sedangkan dari hasil uji ducan multiple range test (DMRT) menunjukkan bahwa jumlah larutan unsur hara terendah dihasilkan pada perlakuan waktu ekstraksi 2 jam dengan suhu $60^{\circ} \mathrm{C}\left(\mathrm{T}_{1} \mathrm{~S}_{1}\right)$. Sedangkan jumlah larutan unsur hara tertinggi dihasilkan pada perlakuan waktu ekstraksi 6 jam dengan suhu $80^{\circ} \mathrm{C}\left(\mathrm{T}_{3} \mathrm{~S}_{3}\right)$. Lama terpaparnya rumput laut Sargassum sp. di dalam larutan $0,3 \% \mathrm{KOH}$ pada suhu $80^{\circ} \mathrm{C}$ telah memudahkan penarikan cairan yang mengandung unsur hara dari dalam talus rumput laut Sargassum sp. Hal ini terjadi, kemungkinan akibat perlakuan suhu ekstraksi sebesar $80^{\circ} \mathrm{C}$ selama 6 jam sehingga lebih banyak cairan yang mengandung unsur hara keluar dibandingkan dengan perlakuan suhu ekstraksi sebesar $60{ }^{\circ} \mathrm{C}$ selama 2 jam. Budiyanto dan Yulianingsih (2008) menyatakan bahwa waktu dan suhu pada proses ekstraksi sangat berkaitan erat dengan hasil akhir suatu produk, semakin lama waktu dan semakin tinggi suhu ekstraksi maka akan mempengaruhi jumlah larutan unsur hara yang dihasilkan.

\section{Nilai N-total}

Hasil penelitian menunjukkan nilai $\mathrm{N}$ total setiap perlakuan berkisar antara 1,56\%-1,70\% dengan nilai tertinggi ditemukan pada perlakuan $\mathrm{T}_{2} \mathrm{~S}_{1}$ sebesar $1,70 \%$ dan terendah pada perlakuan $\mathrm{T}_{1}^{2} \mathrm{~S}_{1}$ sebesar $1,56 \%$. Sementara hasil analisa kandungan $N$ total pada rumput laut sebelum diberi perlakuan ditemukan sebesar $5,35 \%$. Rendahnya penarikan N-total dari talus rumput laut Sargassum sp. kemungkinan terjadi karena N-total yang ada dalam talus rumput laut Sargassum sp. terikat kuat dengan bahan pendukung struktur talus rumput laut Sargassum sp.; di samping 


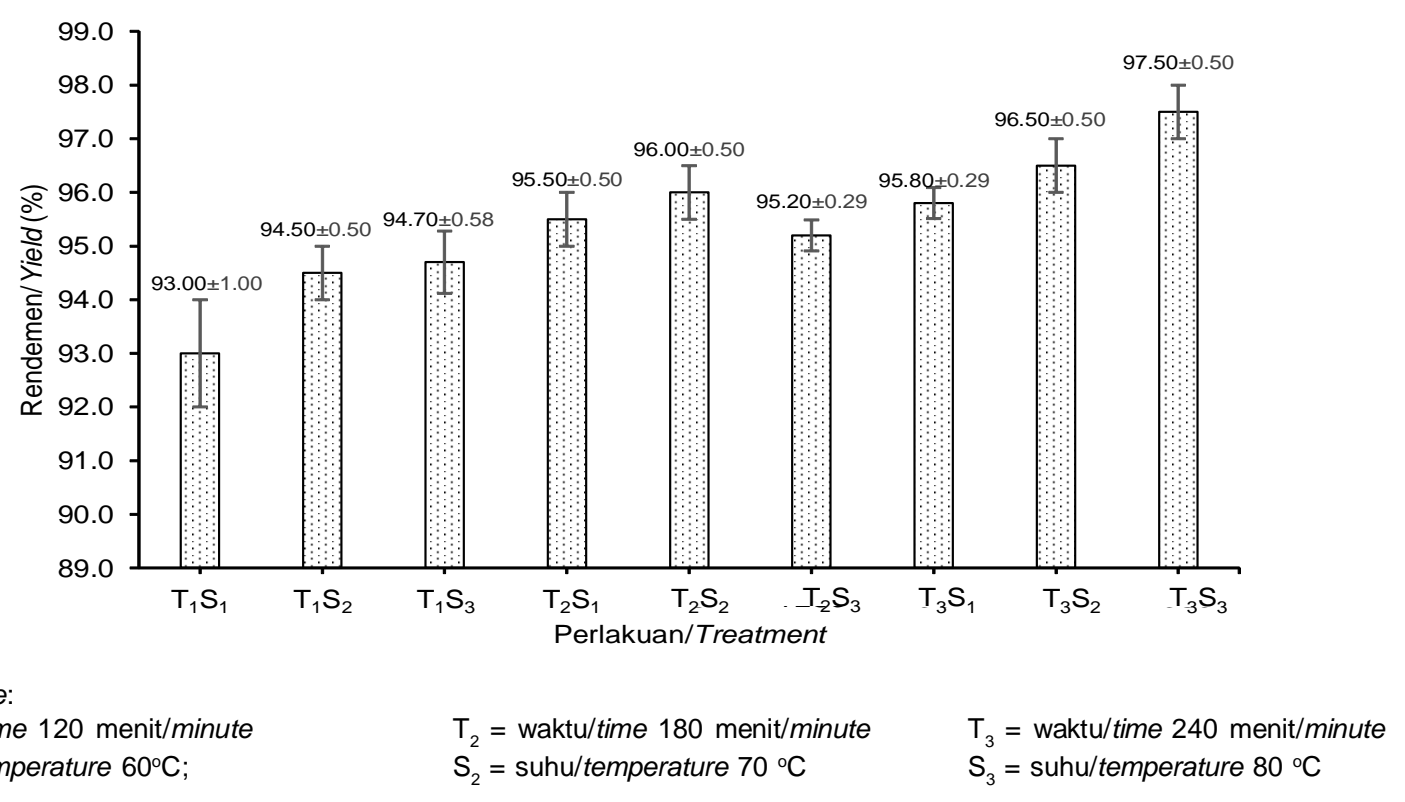

Catatan/Note:

$\mathrm{T}_{1}=$ waktu/time $120 \mathrm{menit} /$ minute

$\mathrm{S}_{1}=$ suhu/temperature $60^{\circ} \mathrm{C}$;

$\mathrm{T}_{2}=$ waktu/time $180 \mathrm{menit} /$ minute

$\mathrm{T}_{3}=$ waktu/time $240 \mathrm{menit} /$ minute

Gambar 1. Jumlah larutan unsur hara makro terekstrak dari rumput laut Sargassum sp.

Figure 1. Total macro nutrient solution extracted from seaweed Sargassum sp.

itu adanya proses panas dan perlakuan alkali telah menyebabkan sebagian protein terkoagulasi. Diketahui bahwa protein akan terdenaturasi pada suhu 60-70 ${ }^{\circ} \mathrm{C}$ sedangkan dalam perlakuan yang diberikan suhu ekstraksi berkisar antara $60-80^{\circ} \mathrm{C}$. Kemungkinan lain adalah $\mathrm{N}$-total yang mudah larut saja yang dapat ditarik dari dalam talus Sargassum sp. Hasil uji statistik kadar nitrogen pada semua perlakuan menunjukkan bahwa nilai tertinggi terdapat pada perlakuan $\mathrm{T}_{2} \mathrm{~S}_{1}(1,70 \%)$, dan tidak berbeda nyata dengan perlakuan $\mathrm{T}_{3} \mathrm{~S}_{1}(1,67 \%) ; \mathrm{T}_{3} \mathrm{~S}_{3}(1,64 \%) ; \mathrm{T}_{2} \mathrm{~S}_{2}$ $(1,63 \%) ; T_{2} S_{3}(1,61 \%) ; T_{1} S_{2}(1,59 \%) ;$ dan $T_{1} S_{3}$ yang mempunyai nilai sama $\mathrm{T}_{3} \mathrm{~S}_{2}(1,58 \%)$, tetapi berbeda nyata dengan perlakuan $T_{1} S_{1}(1,56 \%)$. Sedangkan nilai terendah terdapat pada perlakuan $\mathrm{T}_{1} \mathrm{~S}_{1}$ dengan nilai $(1,56 \%)$. Merujuk pada hasil penelitian ini terbukti bahwa perlakuan suhu dan lamanya waktu ekstraksi telah berpengauh terhadap penarikan $\mathrm{N}$-total dari dalam

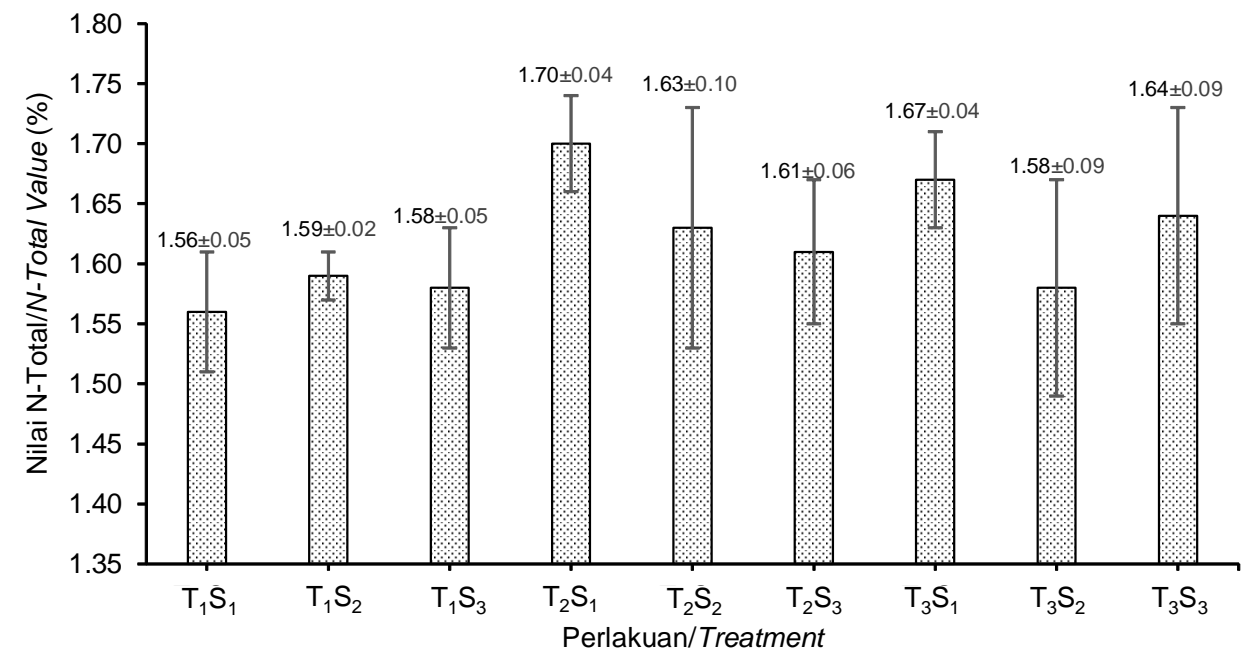

\section{Catatan/Note:}

$\mathrm{T}_{1}=$ waktu/time $120 \mathrm{menit} /$ minute

$\mathrm{S}_{1}=$ suhu/temperature $60^{\circ} \mathrm{C}$;

$$
\begin{aligned}
& \mathrm{T}_{2}=\text { waktu/time } 180 \mathrm{menit} / \text { minute } \\
& \mathrm{S}_{2}=\text { suhu/temperature } 70^{\circ} \mathrm{C}
\end{aligned}
$$

$\mathrm{T}_{3}=$ waktu/time $240 \mathrm{menit} /$ minute

$\mathrm{S}_{3}=$ suhu/temperature $80^{\circ} \mathrm{C}$

Gambar 2. Nilai N total larutan unsur hara dari ekstrak rumput laut Sargassum sp.

Figure 2. Total $N$ in the nutrient solution extracted from seaweed Sargassum sp. 
talus Sargassum sp. Basmal et al (2015) melaporkan pada rumput laut Sargassum sp. yang diberi perlakuan perendaman dalam larutan $\mathrm{KOH} 0,3 \%$ kemudian diekstrak cairannya diperoleh nilai $\mathrm{N}$-total sebesar 0,78\%. Menurut Ibrahim, Yunita, dan Feronika (2015) serta Handayani dan Sriherfyna (2016), peningkatan waktu dan suhu ekstraksi yang tinggi dapat menyebabkan beberapa senyawa pada larutan menguap, selain itu komponen bioaktif yang tidak tahan terhadap suhu tinggi akan mengalami perubahan struktur dan menghasilkan ekstrak yang rendah; sebaliknya suhu ekstraksi yang rendah dan waktu ekstraksi singkat menghasilkan rendemen yang rendah. Pada Gambar 2 dapat dilihat nilai N-total masing masing perlakuan.

\section{Kadar Kalium}

Hasil penelitian kandungan Kalium $\left(\mathrm{K}^{+}\right)$di dalam ekstrak cair Sargassum sp. untuk semua perlakuan berada pada kisaran 201,2-206,9 ppm dengan nilai tertinggi ditemukan pada perlakuan $\mathrm{T}_{3} \mathrm{~S}_{2}$ sebesar 206,9 ppm, sedangkan yang terendah pada perlakuan $\mathrm{T}_{2} \mathrm{~S}_{2}$ sebesar 201,2 ppm. Pada perlakuan waktu 120 menit dengan variasi suhu 60,70 dan $80^{\circ} \mathrm{C}$ nilai $\mathrm{K}^{+}$ relatif mempunyai nilai yang konstan, sedangkan pada waktu 180 dan 240 menit dengan variasi suhu 60, 70 dan $80^{\circ} \mathrm{C}$ nilai $\mathrm{K}^{+}$berfluktuasi. Hasil uji statistik antara perlakuan waktu yang diberikan menunjukkan ada perbedaan nyata sedangkan perlakuan suhu 60,70 dan $80^{\circ} \mathrm{C}$ tidak menunjukkan perbedaan nyata. Antar perlakuan waktu dan suhu ekstraksi menunjukkan ada perbedaan yang nyata pada taraf 5\% (Gambar 3). Perlakuan $\mathrm{T}_{1} \mathrm{~S}_{1}, \mathrm{~T}_{1} \mathrm{~S}_{2}$ dan $\mathrm{T}_{1} \mathrm{~S}_{3}$ tidak berbeda nyata tetapi dengan perlakuan $T_{2} S_{1}, T_{2} S_{2}, T_{2} S_{3}, T_{3} S_{1}, T_{1} S_{2}$ dan $\mathrm{T}_{3} \mathrm{~S}_{2}$ menunjukkan perbedaan yang nyata. Basmal, Kusumawati dan Nurhayati (2016) melaporkan kandungan $\mathrm{K}^{+}$dalam talus rumput laut Sargassum sp. adalah 3,34\% atau setara dengan 33.440,43 ppm, sedangkan pada penelitian ini jumlah ion $\mathrm{K}^{+}$yang dapat ditarik dari dalam talus Sargassum hanya sebesar 206,9 ppm artinya perlakuan suhu dan waktu yang diberikan tidak dapat mengekstrak semua ion $\mathrm{K}^{+}$yang ada dalam talus Sargassum $\mathrm{sp}$. Hal ini mungkin selama perlakuan perendaman dalam larutan $\mathrm{KOH} \mathrm{0,3 \%}$ telah terjadi reaksi antara $\mathrm{KOH}$ dengan cairan alginat membentuk potasium alginat (K-alginat). Berdasarkan hasil penelitian maka suhu dan waktu kontak talus dengan media ekstraksi yakni larutan $\mathrm{KOH} 0,3 \%$ dapat mempengaruhi kelarutan ion $\mathrm{K}^{+}$yang berasal dari dalam talus rumput laut Sargassum sp.

\section{Kadar Fosfat $\left(\mathrm{P}_{2} \mathrm{O}_{5}\right)$}

Hasil analisis kadar $\mathrm{P}_{2} \mathrm{O}_{5}$ dalam ekstrak cair Sargassum sp. pada semua perlakuan perbedaan waktu dan suhu proses berkisar antara 132,8-197,7 ppm dengan nilai tertinggi ditemukan pada perlakuan $\mathrm{T}_{3} \mathrm{~S}_{3}(197,7 \mathrm{ppm})$ dan berbeda nyata dengan seluruh perlakuan yang diberikan. Sedangkan nilai terendah terdapat pada perlakuan $\mathrm{T}_{1} \mathrm{~S}_{1}(132,8 \mathrm{ppm})$. Hasil tersebut menunjukkan bahwa kadar phospat dari ekstrak cair rumput laut Sargassum sp. tergolong sangat rendah, yaitu di bawah $1 \%$. Basmal, Widanarto,

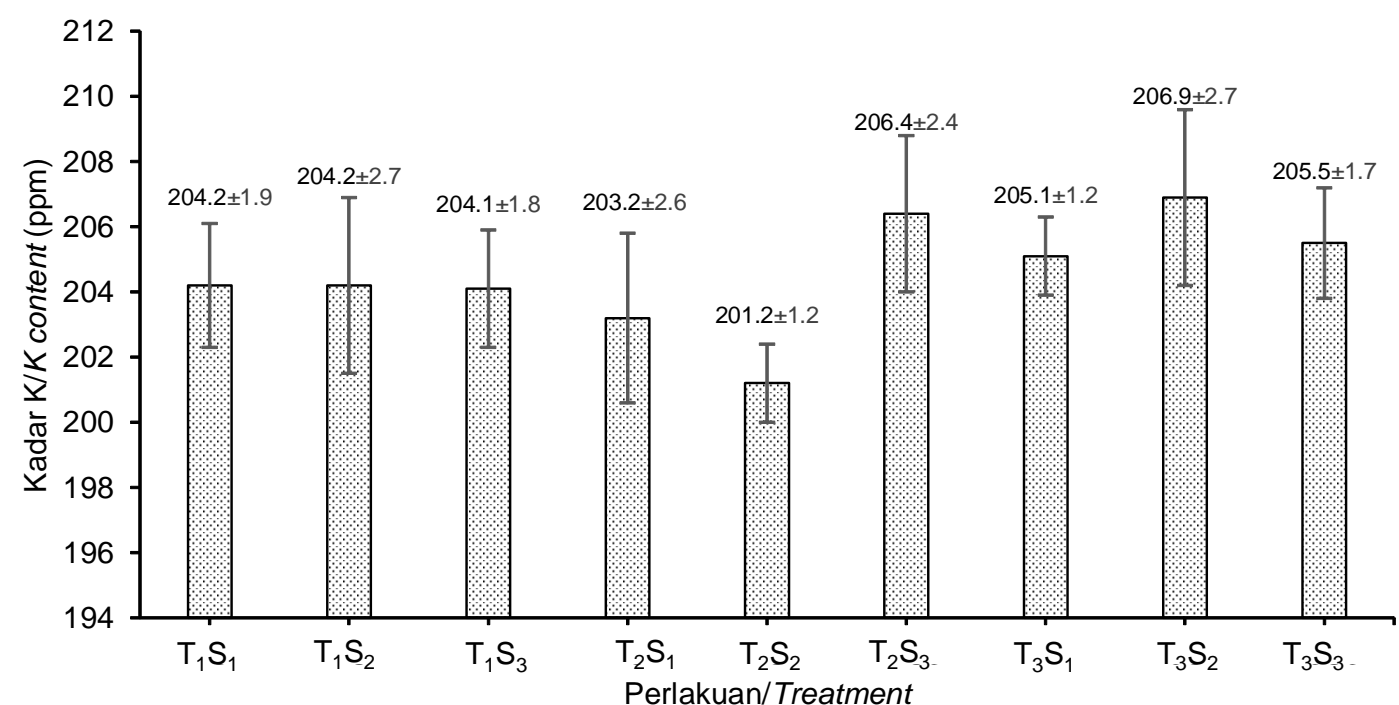

Catatan/Note:

$\mathrm{T}_{1}=$ waktu/time 120 menit/minute

$\mathrm{S}_{1}=$ suhu/temperature $60^{\circ} \mathrm{C}$;
$\mathrm{T}_{2}=$ waktu/time $180 \mathrm{menit} /$ minute

$\mathrm{S}_{2}=$ suhu/temperature $70^{\circ} \mathrm{C}$
$\mathrm{T}_{3}=$ waktu/time $240 \mathrm{menit} /$ minute

$\mathrm{S}_{3}=$ suhu/temperature $80^{\circ} \mathrm{C}$

Gambar 3. Kandungan ion $\mathrm{K}^{+}$dalam larutan unsur hara dari ekstrak rumput laut Sargassum sp.

Figure 3. Ion $\mathrm{K}^{+}$content in the nutrient solution extracted from seaweed Sargassum $s p$. 


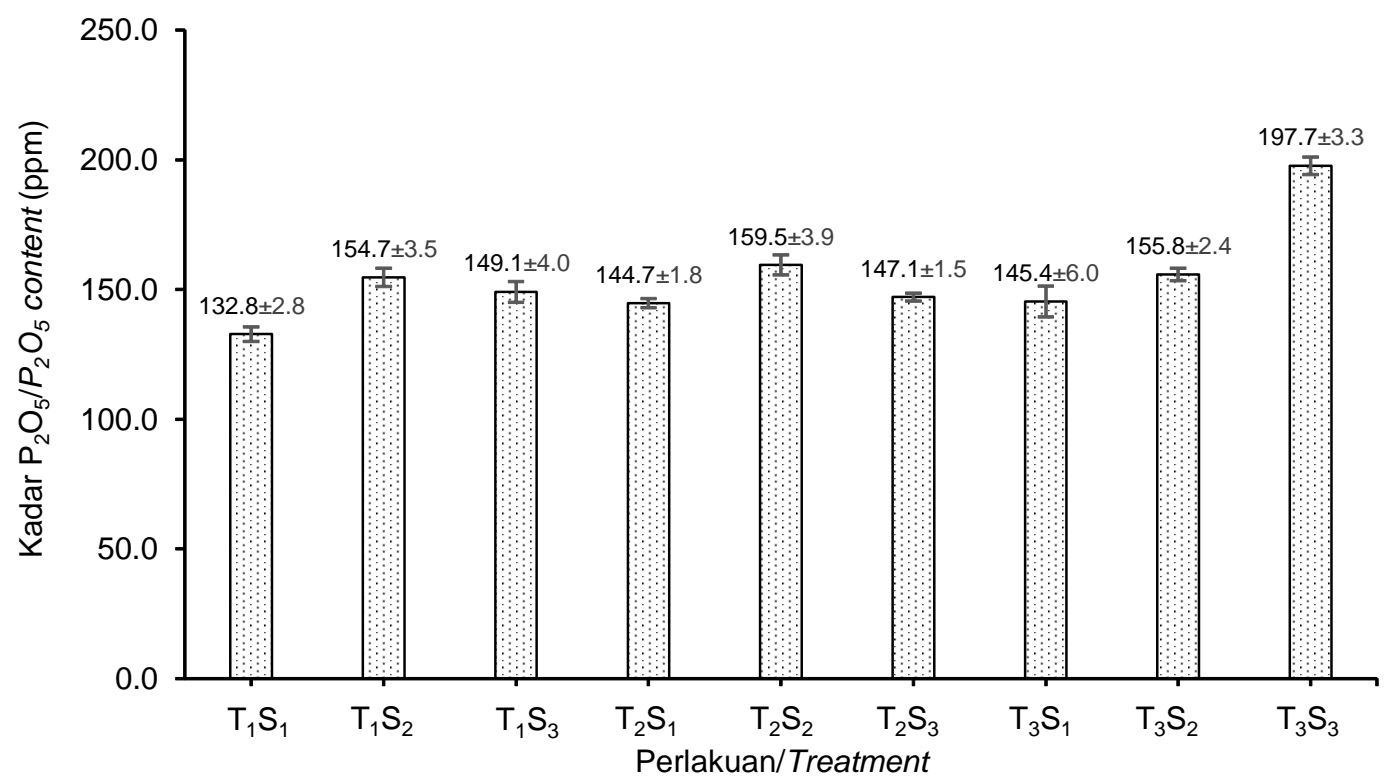

Catatan/Note:

$\mathrm{T}_{1}=$ waktu/time $120 \mathrm{menit} /$ minute

$\mathrm{S}_{1}=$ suhu/temperature $60^{\circ} \mathrm{C}$
$\mathrm{T}_{2}=$ waktu/time $180 \mathrm{menit} /$ minute

$\mathrm{S}_{2}=$ suhu/temperature $70^{\circ} \mathrm{C}$
$\mathrm{T}_{3}=$ waktu/time $240 \mathrm{menit} /$ minute

$\mathrm{S}_{3}=$ suhu/temperature $80^{\circ} \mathrm{C}$

Gambar 4. Nilai $\mathrm{P}_{2} \mathrm{O}_{5}$ dalam larutan unsur hara dari ekstrak rumput laut Sargassum sp.

Figure 4. $P_{2} \mathrm{O}_{5}$ content in the nutrient solution extracted from seaweed Sargassum $s p$.

Kusumawati dan Utomo (2014) menyatakan bahwa kandungan fosfat pada rumput laut coklat Sargassum sp. berada pada kisaran $0,05 \%$ atau setara dengan $500 \mathrm{ppm}$. Phospat di dalam talus rumput laut terikat kuat dengan bahan penyusun talus Sargassum sp., sehingga untuk memisahkan phospat dari bahan lain diperlukan energi yang cukup tinggi. Pada penelitian ini telah dicoba kombinasi waktu dan suhu ekstraksi yang berbeda untuk melarutkan kandungan fosfat yang terdapat pada talus Sargassum sp., yaitu menggunakan larutan $\mathrm{KOH} 0,3 \%$. Diharapkan $\mathrm{P}_{2} \mathrm{O}_{5}$ yang tertarik ke luar dari dalam talus Sargassum sp. dapat bereaksi dengan $\mathrm{KOH}$ membentuk $\mathrm{K}_{3} \mathrm{PO}_{4}$ atau $\mathrm{KH}_{2} \mathrm{PO}_{4}$ yang keduanya sangat bermanfaat untuk pertumbuhan tanaman. Pada pemberian perlakuan panas hingga $80^{\circ} \mathrm{C}$ selama 240 menit, jumlah $\mathrm{P}_{2} \mathrm{O}_{5}$ yang dapat ditarik ke luar dari talus Sargassum sp. 197,7 $\pm 3,3$ ppm sedangkan jumlah $\mathrm{P}_{2} \mathrm{O}_{5}$ di dalam talus Sargassum sp. sebesar 500 ppm. Efektifitas perlakuan suhu $80^{\circ} \mathrm{C}$ selama 240 menit dalam media pelarut $\mathrm{KOH} 0,3 \%$ tercapai sebesar $39,5 \%$. Tidak maksimumnya proses penarikan $\mathrm{P}_{2} \mathrm{O}_{5}$ dari dalam talus Sargassum sp. kemungkinan disebabkan suhu dan waktu yang diberikan belum ef ektif memisahkan $\mathrm{P}_{2} \mathrm{O}_{5}$ dari struktur bangunan talus Sargassum sp. Menurut Situngkir (2017) fosfat dalam bentuk sodium fosfat yang ditambahkan ke dalam sodium alginat mempunyai kekuatan tarik yang lebih besar dibandingkan dengan menambahkan kalsium oksalat.

\section{Nilai $\mathbf{C}_{\text {organik }}$}

Bahan organik merupakan senyawa organik komplek yang sedang berkumpul dan sedang atau telah mengalami proses dekomposisi atau pelapukan akibat pengaruh lingkungan, dapat berupa humus hasil humifikasi ataupun senyawa anorganik hasil mineralisasi, termasuk juga mikroba heterotrofik dan ototrofik yang terlibat di dalamnya (Madjid, 2008 dalam $\left.A^{A n o n}{ }^{2}, 2009\right)$. Dalam penelitian ini ditemukan hasil analisis kadar $\mathrm{C}_{\text {Organik }}$ seperti terlihat pada Gambar 5 yang menunjukkan nilai tertinggi pada perlakuan $\mathrm{T}_{3} \mathrm{~S}_{3}$ $(0,55 \%)$, yang tidak berbeda nyata dengan perlakuan $\mathrm{T}_{2} \mathrm{~S}_{3}(0,54 \%)$, tetapi berbeda nyata dengan perlakuan lainnya. Sedangkan nilai terendah terdapat pada perlakuan $T_{1} S_{1}$ dan $T_{1} S_{2}(0,47 \%)$.

Hasil analisis $\mathrm{C}_{\text {Organik }}$ sampel cairan ekstrak Sargassum sp. (Gambar 5.) menunjukkan bahwa pemberian lama waktu ekstraksi $(T)$ berpengaruh nyata $(p<0,05)$ terhadap ekstrak cair Sargassum sp. yang dihasilkan. Sedangkan pemberian perlakuan suhu ekstraksi tidak berpengaruh nyata $(p>0,05)$. Hal tersebut juga diikuti dengan korelasi antara kedua perlakuan yang tidak berpengaruh nyata pada taraf 


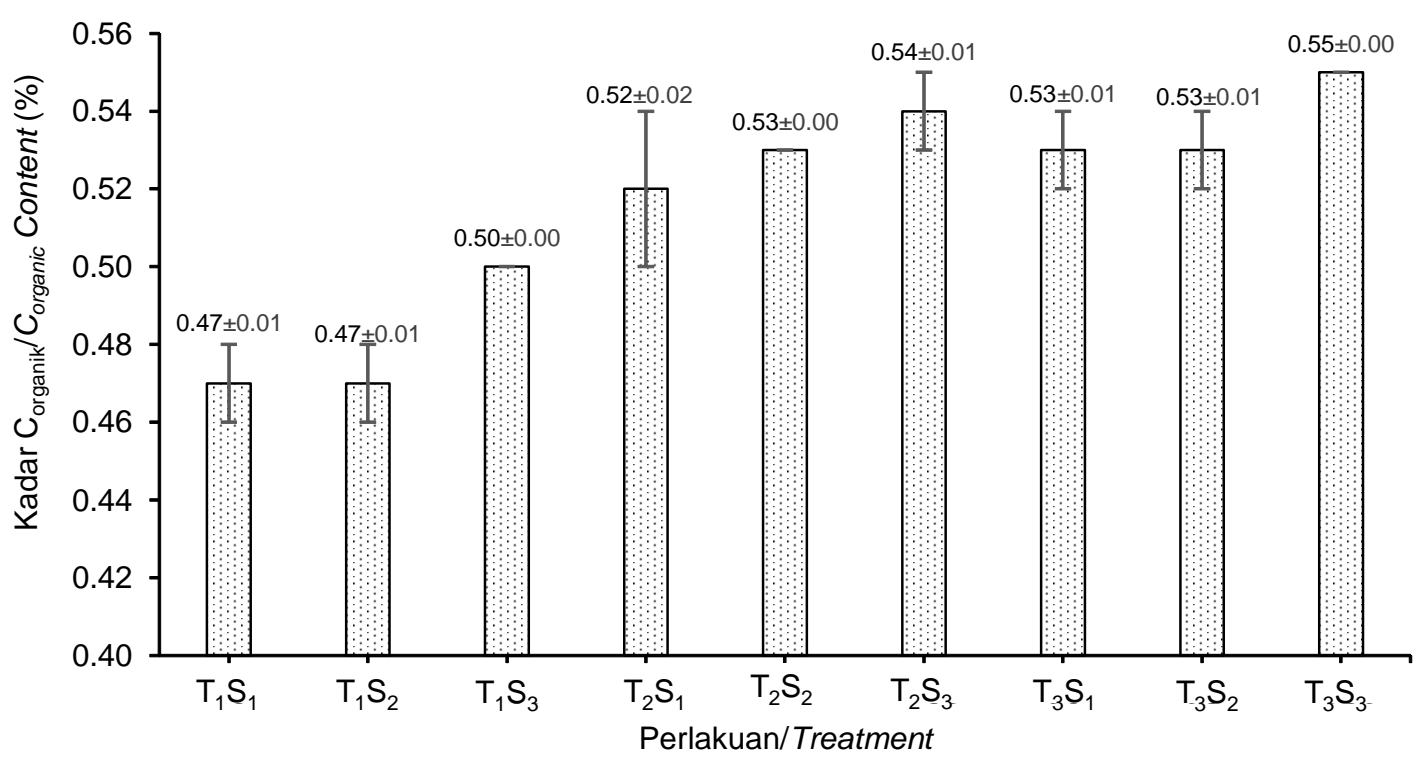

Catatan/Note:

$\mathrm{T}_{1}=$ waktu/time $120 \mathrm{menit} /$ minute

$\mathrm{S}_{1}=$ suhu/temperature $60^{\circ} \mathrm{C}$

$\mathrm{T}_{2}=$ waktu/time $180 \mathrm{menit} /$ minute

$\mathrm{S}_{2}=$ suhu/temperature $70^{\circ} \mathrm{C}$
$\mathrm{T}_{3}=$ waktu/time $240 \mathrm{menit} /$ minute

$\mathrm{S}_{3}=$ suhu/temperature $80^{\circ} \mathrm{C}$

Gambar 5. Kandungan $\mathrm{C}_{\text {organik }}$ dalam larutan unsur hara dari ekstrak rumput laut Sargassum sp.

Figure 5. $C_{\text {organic }}$ content in the nutrient solution extracted from seaweed Sargassum $s p$.

$95 \%$. Hasil tertinggi diperoleh pada perlakuan waktu ekstraksi 4 jam dan suhu ekstraksi $80^{\circ} \mathrm{CT}_{3} \mathrm{~S}_{3}$ dengan nilai $(0,55 \%)$. $\mathrm{C}_{\text {oranik }}$ adalah hasil dekomposisi dan atau pelapukan bahan bahan organik yang disebabkan oleh proses reaksi yang diberikan terhadap bahan organik tersebut. Menurut Hanafiah (2005), $\mathrm{C}_{\text {organik }}$ adalah bahan-bahan organik yang dapat diperbaharui, didaur ulang, dirombak oleh jasad renik tanah menjadi unsur yang dapat digunakan oleh tanaman tanpa mencemari tanah dan air.

Pada penelitian ini rumput laut Sargassum sp. sebelum diberi perlakuan suhu dan waktu pemasakan yang berbeda telah direndam dalam larutan $\mathrm{KOH} \mathrm{0,3 \%}$ selama 5 hari. Hasil penelitian telah membuktikan bahwa perlakuan suhu tinggi dan waktu yang lebih lama menyebabkan sebagian $\mathrm{C}_{\text {organik }}$ yang ada dalam rumput laut Sargassum sp. terlarut dalam media ekstraksi. Oleh karena itu, perlakuan $\mathrm{T}_{3} \mathrm{~S}_{3}$ menjadi perlakukan yang terbaik dari seluruh perlakuan yang diberikan. $\mathrm{C}_{\text {Organik }}$ berfungsi memperbaiki struktur tanah, aerasi tanah, meningkatkan daya penyangga air tanah, menurunkan laju erosi, menyangga dan menyediakan hara tanaman, meningkatkan efisiensi pemupukan, menetralkan sifat racun $\mathrm{Al}$ dan $\mathrm{Fe}$, serta sebagai sumber energi bagi jasad renik/mikroba tanah yang mampu melepaskan hara bagi tanaman (Mulyanto, 2004 dan Anon, 2011b).

\section{Nilai rasio $\mathrm{C} / \mathrm{N}$}

Rasio C/N merupakan gambaran mudah tidaknya bahan organik dilapukkan dan tingkat kematangan dari bahan organik tersebut serta mobilisasi $\mathrm{N}$ pada tanah (Anonc, 2013). Rasio C/N dalam penelitian ini berkisar antara 0,3-0,34 dengan nilai tertinggi ditemukan pada perlakuan $\mathrm{T}_{3} \mathrm{~S}_{2}$ dan $\mathrm{T}_{3} \mathrm{~S}_{3}$ sebesar 0,34 dan terendah pada perlakuan $T_{1} S_{1}$ dan $T_{1} S_{2}$ sebesar 0,30 (Gambar 6). Kadar rasio $\mathrm{C} / \mathrm{N}$ dari ekstrak cairan Sargassum $\mathrm{sp}$. tersebut tergolong relatif rendah dibandingkan standar SNI yang sudah ditetapkan. Menurut Hanafiah (2005) nisbah $\mathrm{C} / \mathrm{N}$ yang $\leq 20$ menunjukkan terjadinya mineralisasi unsur $\mathrm{N}$ dan bahan organik tersebut mudah untuk dirombak; sementara Peraturan Menteri Pertanian Nomor 70/Permentan/SR.140/10/2011 telah mensyaratkan $\mathrm{C}_{\text {organik }}$ minimum dalam pupuk cair adalah $6 \%$.

Rasio $\mathrm{C} / \mathrm{N}$ dari hasil penelitian ditemukan 20,6. Rendahnya rasio $\mathrm{C} / \mathrm{N}$ pada semua perlakuan kemungkinan disebabkan $\mathrm{C}_{\text {organik }}$ dan $\mathrm{N}$ yang ada dalam talus rumput laut Sargassum sp. tidak maksimum tertarik dari dalam talus. Pada penelitian ini digunakan rumput laut segar, sedangkan $\mathrm{C}_{\text {organik }}$ berasal dari proses dekomposisi talus. Penarikan $\mathrm{C}_{\text {organik }}$ dari bahan yang telah terdekomposisi lebih mudah dibandingkan pada bahan baku pupuk yang masih segar (Anon, 2013c). 


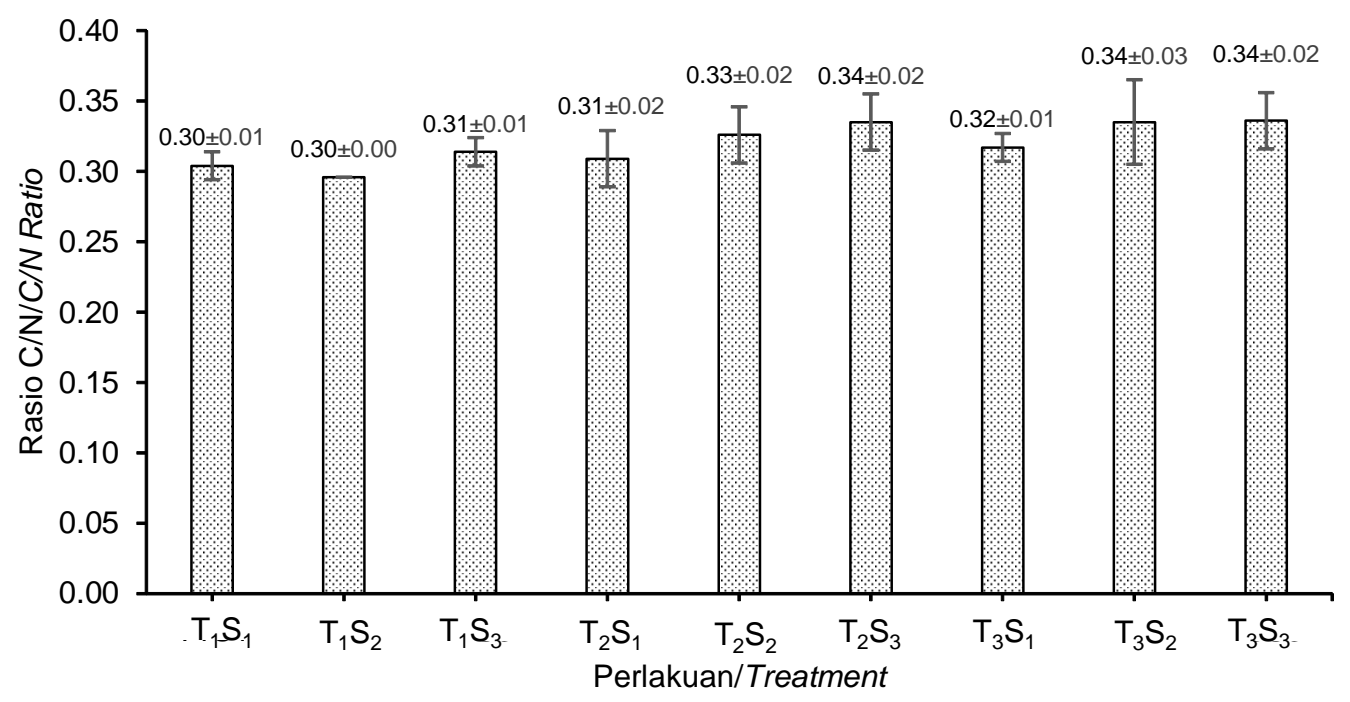

\footnotetext{
Catatan/Note:

$\mathrm{T}_{1}=$ waktu/time $120 \mathrm{menit} /$ minute

$\mathrm{S}_{1}=$ suhu/temperature $60^{\circ} \mathrm{C}$
}

$$
\begin{aligned}
& \mathrm{T}_{2}=\text { waktu/time } 180 \mathrm{menit} / \text { minute } \\
& \mathrm{S}_{2}=\text { suhu/temperature } 70^{\circ} \mathrm{C}
\end{aligned}
$$

$$
\begin{aligned}
& \mathrm{T}_{3}=\text { waktu/time } 240 \text { menit } / \text { minute } \\
& \mathrm{S}_{3}=\text { suhu/temperature } 80^{\circ} \mathrm{C}
\end{aligned}
$$

Gambar 6. Rasio C/N dalam larutan unsur hara dari ekstrak rumput laut Sargassum sp.

Figure 6. $\mathrm{C} / \mathrm{N}$ ratio in the nutrient solution extracted from seaweed Sargassum $\mathrm{sp}$.

Perlakuan suhu dan waktu ekstraksi yang diberikan tidak cukup kuat menarik $\mathrm{C}_{\text {organik }}$ dari dalam talus Sargassum sp. Dalzell, Biddlestone, Gray, dan Thurairajan (1987) melaporkan proses pengomposan bahan organik sangat dipengaruhi oleh beberapa faktor di antaranya adalah nilai perbandingan (nisbah) $\mathrm{C} / \mathrm{N}$ di awal pengomposan. Jika Nilai $\mathrm{C} / \mathrm{N}$ pupuk organik semakin besar menunjukkan bahwa bahan organik belum terdekomposisi dengan baik. Sebaliknya nilai $\mathrm{C} / \mathrm{N}$ pupuk organik semakin rendah menunjukkan bahwa bahan organik sudah terdekomposisi. Proses pengomposan bahan baku pupuk di samping dipengaruhi oleh aktifitas ezim yang ada dalam bahan baku pupuk, juga dipengaruhi oleh aktifitas mikroba dekomposer. Selanjutnya dilaporkan juga oleh Dalzell et al. (1987) bahwa kecepatan pelapukan bahan baku pupuk akan dipengaruhi oleh faktor lingkungan (suhu, tingkat kelembaban, waktu dan jenis media pelarut) untuk melapukkan bahan baku pupuk. Pada penelitian ini telah digunakan larutan $\mathrm{KOH}$ yang mempunyai nilai $\mathrm{pH}$ relative lebih tinggi yakni sebesar $\mathrm{pH}$ 9. Tingginya nilai $\mathrm{pH}$ telah menyebabkan mikroba dekomposer tidak maksimum mendekomposer talus Sargassum sp. Hasil penelitian juga menunjukkan angka lempengan total cenderung menurun selama proses ekstraksi cairan Sargassum sp., hal ini menunjukkan bahwa proses dekomposisi tidak berjalan dengan baik. Proses dekomposisi dapat dilakukan secara biologi, mekanik/fisik dan proses kimia. Pada penelitian ini proses dekomposisi talus menggunakan proses dekomposisi kimia, hal ini yang memungkinkan rasio $\mathrm{C} / \mathrm{N}$ sangat rendah.

\section{pH}

Hasil pengukuran nilai $\mathrm{pH}$ untuk semua perlakuan menunjukkan nilai pH 9. Menurut Permentan (2011), syarat $\mathrm{pH}$ pada suatu pupuk organik cair berada pada angka antara 4-9. Menurut Sutiyoso ( 2003) nilai pH pada media tanaman berfungsi sebagai penghantar unsur hara yang akan diserap oleh tanaman karena setiap tanaman memiliki batas $\mathrm{pH}$ yang optimal untuk meningkatkan pertumbuhan suatu tanaman.

\section{Nilai Kekentalan}

Hasil penelitian menunjukkan nilai kekentalan cairan ekstrak Sargassum sp. berkisar antara 2,73,1 cPs dengan nilai kekentalan tertinggi ditemukan pada perlakuan $\mathrm{T}_{1} \mathrm{~S}_{1}$ dan $\mathrm{T}_{3} \mathrm{~S}_{3}$ sebesar $3,1 \mathrm{cPS}$ sedangkan yang terendah ditemukan pada perlakuan $\mathrm{T}_{3} \mathrm{~S}_{1}$ sebesar 2,7 cPs. Berdasarkan hasil uji statistik antara perlakuan $\mathrm{T}_{1} \mathrm{~S}_{1}$ dan $\mathrm{T}_{3} \mathrm{~S}_{3}$ tidak menunjukkan adanya perbedaan yang nyata nilai kekentalan yang dihasilkan yakni sebesar $3.1 \mathrm{cPs}$. Antar perlakuan $\mathrm{T}_{2} \mathrm{~S}_{1}, \mathrm{~T}_{2} \mathrm{~S}_{2}$ dan $\mathrm{T}_{2} \mathrm{~S}_{3}$ juga tidak menunjukkan perbedaan nilai kekentalan $(\mathrm{P}<0,05)$, tetapi berbeda nyata dengan perlakuan $T_{1} S_{2}, T_{1} S_{3}$ dan $T_{3} S_{1}$ ( Gambar 7). Perlakuan waktu 120 menit dan 240 menit dengan variasi suhu 60,70 dan $80{ }^{\circ} \mathrm{C}$ mempengaruhi nilai kekentalan cairan ekstrak Sargassum sp. Hal ini terjadi karena 


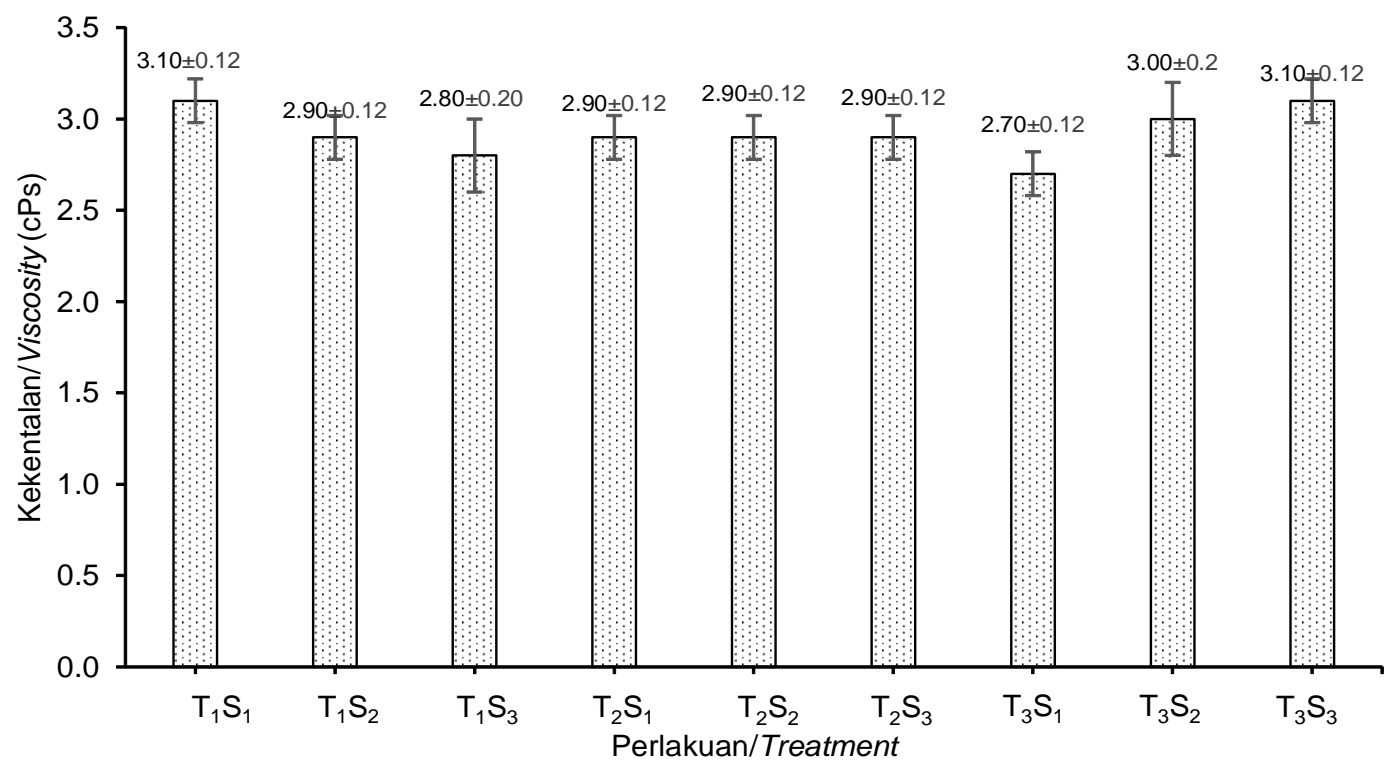

Catatan/Note:

$\mathrm{T}_{1}=$ waktu/time $120 \mathrm{menit} /$ minute

$\mathrm{S}_{1}=$ suhu/temperature $60^{\circ} \mathrm{C}$
$\mathrm{T}_{2}=$ waktu/time $180 \mathrm{menit} /$ minute $\mathrm{S}_{2}=$ suhu/temperature $70^{\circ} \mathrm{C}$
$\mathrm{T}_{3}=$ waktu/time $240 \mathrm{menit} /$ minute

$\mathrm{S}_{3}^{3}=$ suhu/temperature $80^{\circ} \mathrm{C}$

Gambar 7. Nilai kekentalan larutan unsur hara dari ekstrak rumput laut Sargassum sp.

Figure 7. Viscosity of the nutrient solution extracted from seaweed Sargassum sp.

perlakuan tersebut telah menyebabkan sejumlah alginat ke luar dari talus. Menurut Subaryono dan Apriani (2010) dalam proses ekstraksi alginat dari rumput laut Sargassum sp. menggunakan kisaran suhu $60-70^{\circ} \mathrm{C}$ selama 2 jam akan merilis alginat yang ada dalam talus Sargassum sp. Komponen alginat dapat secara utuh ditarik pada kondisi asam dan suhu yang tinggi (Winarno, 1990). Sedangkan perlakuan waktu ekstraksi 180 menit dengan variasi suhu ekstraksi 60,70 dan $80{ }^{\circ} \mathrm{C}$ tidak memberikan perbedaan signifikan terhadap nilai kekentalan. Pada perlakuan waktu ekstraksi 120 menit dengan variasi suhu 60,70 an $80^{\circ} \mathrm{C}$ terjadi penurunan nilai kekentalan yakni semakin tinggi suhu, nilai kekentalan semakin menurun, sebaliknya pada perlakuan waktu 240 menit dengan variasi suhu 60,70 dan $80^{\circ} \mathrm{C}$, nilai kekentalan perlakuan meningkat dengan meningkatnya suhu ekstraksi. Sedangkan pada perlakuan waktu 180 menit dengan variasi suhu 60,70 dan $80^{\circ} \mathrm{C}$ nilai kekentalan tidak menunjukkan perbedaan. Tingginya nilai kekentalan pada perlakuan $T_{1} S_{1}$ mungkin disebabkan oleh alginat yang berada pada talus tertarik dan bereaksi dengan larutan $\mathrm{KOH} 0,3 \%$. Reaksi antara alginat dengan $\mathrm{KOH}$ akan membentuk larutan kalium alginat yang kental.

\section{Angka Lempeng Total (ALT)}

Nilai ALT pada cairan ekstrak Sargassum sp. berkisar antara $2,5 \times 10^{3}- \pm 0,0$ sampai dengan $7,1 \times$
$10^{3} \pm 0,25$ dengan nilai tertinggi kandungan ALT pada perlakuan $T_{1} S_{1}$ sedangkan yang terendah pada perlakuan $\mathrm{T}_{3} \mathrm{~S}_{3}$ (Gambar 8). Hasil penelitian menemukan adanya korelasi antara perbedaan lama waktu dan suhu ekstraksi terhadap kandungan mikroba dalam cairan ekstrak Sargassum sp. yakni semakin lama waktu ekstraksi dan semakin tinggi suhu perlakuan maka kandungan mikroba dalam cairan ekstrak Sargassum sp. semakin kecil. Pertumbuhan mikroba dipengaruhi oleh faktor lingkungan seperti media tumbuh, suhu dan lama kontak mikroba dengan lingkungan hidupnya. Pada perlakuan ini, mikroba tumbuh di talus rumput laut Sargassum sp. sedangkan media penghalangnya adalah larutan $\mathrm{KOH}$,3\% yang dibiarkan kontak hingga 240 menit pada suhu yang berbeda. Pada perlakuan $\mathrm{T}_{1} \mathrm{~S}_{1}$ lama kontak 120 menit pada suhu $60^{\circ} \mathrm{C}$ beberapa mikroba masih dapat bertahan hidup namun setelah waktu dan suhu ekstraksi ditingkatkan pertumbuhan mikroba menjadi menurun (Gambar 8). Dalam penelitian ini mikroba yang ada di permukaan dan di dalam talus rumput laut Sargassum sp. menurun setelah diberi perlakuan suhu dan waktu kontak yang lebih besar. Hal ini terbukti pada perlakuan $\mathrm{T}_{3} \mathrm{~S}_{3}$ yakni lama kontak 240 menit pada suhu $80{ }^{\circ} \mathrm{C}$, kandungan ALT lebih rendah dibandingkan dengan perlakuan lainnya. Hasil analisa statistik persamaan garis ditemukan bentuk persamaan logaritma $y=-2,116 \ln (x)+7,776$ dengan 


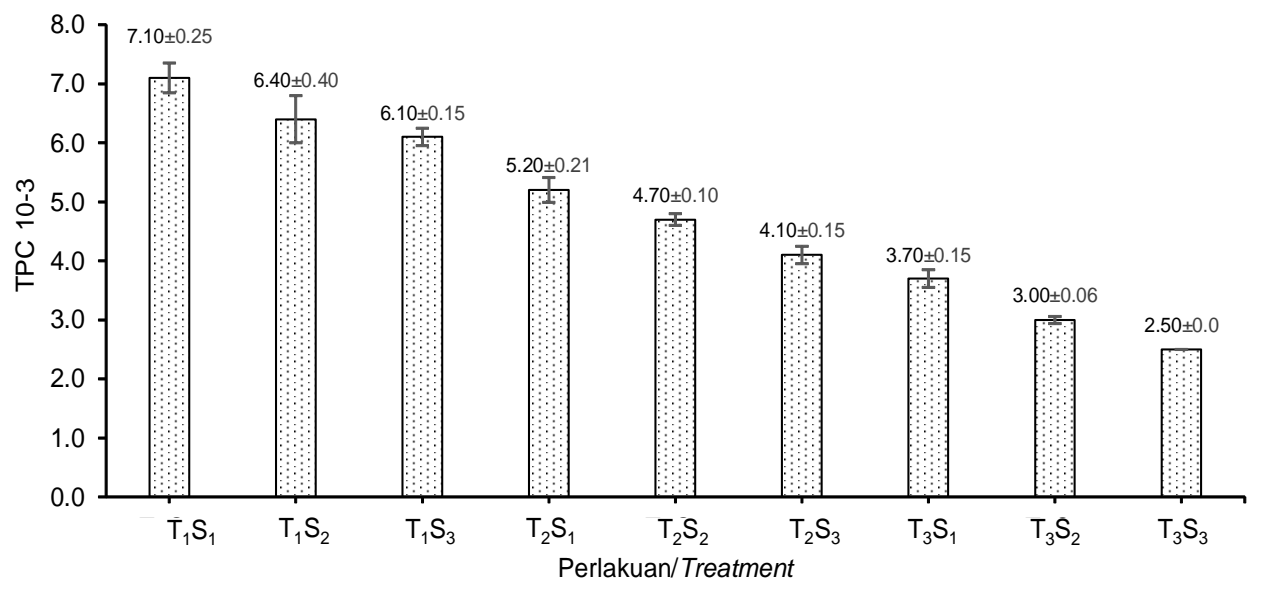

Catatan/Note:

$\mathrm{T}_{1}=$ waktu/time $120 \mathrm{menit} /$ minute

$\mathrm{S}_{1}=$ suhu/temperature $60^{\circ} \mathrm{C}$

$$
\begin{aligned}
& \mathrm{T}_{2}=\text { waktu/time } 180 \mathrm{menit} / \text { minute } \\
& \mathrm{S}_{2}=\text { suhu/temperature } 70^{\circ} \mathrm{C}
\end{aligned}
$$

$\mathrm{T}_{3}=$ waktu/time $240 \mathrm{menit} /$ minute

$\mathrm{S}_{3}=$ suhu/temperature $80^{\circ} \mathrm{C}$

Gambar 8. Nillai ALT dalam larutan unsur hara dari ekstrak rumput laut Sargassum sp.

Figure 8. ALT value in the nutrient solution extracted from seaweed Sargassum sp.

$\mathrm{R}^{2}=0,9187$. Persamaan tersebut menunjukkan bahwa mikroba akan tumbuh dengan baik apabila faktor lingkungan dan nutrisi dalam media tumbuh cukup tersedia. Dalam penelitian ini media ekstraksi bersifat alkalis sehingga menyebabkan mikroba tidak dapat tumbuh lebih banyak. Peraturan Menteri Pertanian Nomor 70/Permentan/SR.140/10/2011 tentang pupuk organik, pupuk hayati dan pembenah tanah telah menyatakan persyaratan teknis minimal pupuk untuk pembenah tanah hayati untuk kandungan mikroba (bakteri/fungi/aktinomicetes) yaitu $<10^{5} \mathrm{cfu} /$ $\mathrm{ml}$. Hasil penelitian kandungan mikroba pada semua perlakuan berkisar antara $2,5 \times 10^{3} \pm 0,0-7,1 \times 10^{3} \pm$ 0,25 yang menunjukkan masih dalam standar Permentan no 70 tahun 2011.

\section{Nilai Electro Conductivity (EC)}

Kisaran nilai EC pada penelitian ini berada antara 2,23-3,52 mS/cm dengan niai EC tertinggi ditemukan pada perlakuan waktu ekstraksi 4 jam dan suhu ekstraksi $80^{\circ} \mathrm{C}\left(\mathrm{T}_{3} \mathrm{~S}_{3}\right)$ dengan nilai $3,52 \mathrm{mS} / \mathrm{cm}$ kemudian diikuti perlakuan $\mathrm{T}_{3} \mathrm{~S}_{2}$ sebesar $3,49 \mathrm{mS} / \mathrm{cm}$ (Gambar 9). Nilai EC terendah ditemukan pada perlakuan $T_{1} S_{1}$ sebesar 2,23 , hasil tersebut tidak

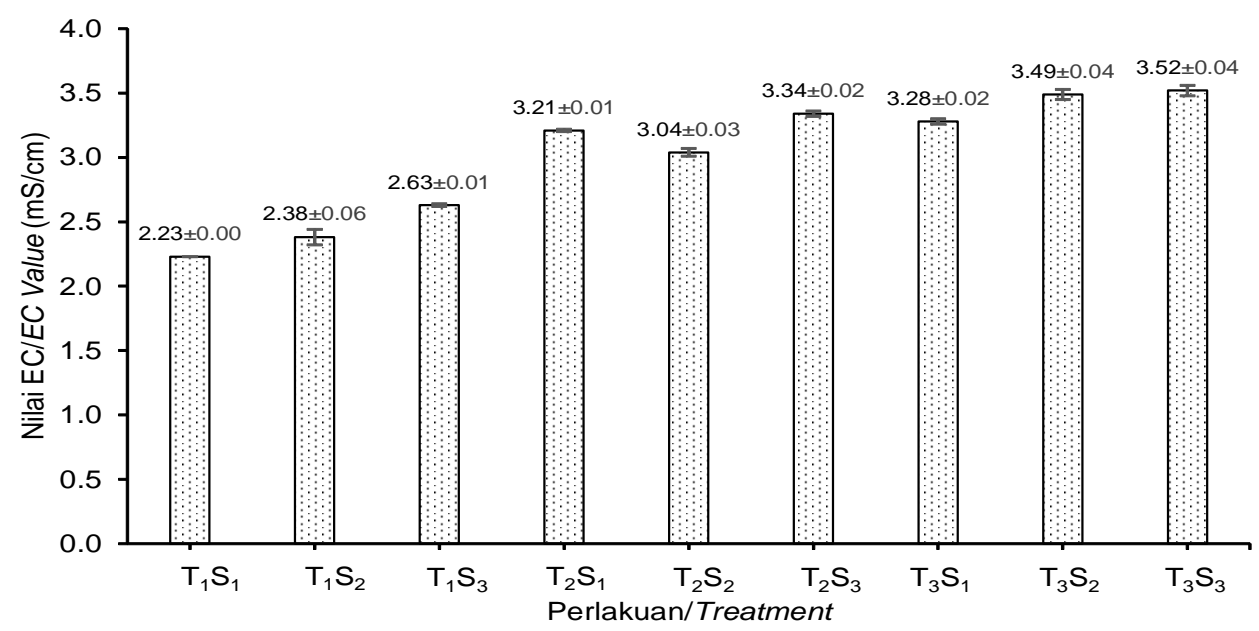

Catatan/Note:

$\mathrm{T}_{1}=$ waktu/time $120 \mathrm{menit} /$ minute

$\mathrm{S}_{1}=$ suhu/temperature $60^{\circ} \mathrm{C}$
$\mathrm{T}_{2}=$ waktu/time $180 \mathrm{menit} /$ minute

$\mathrm{S}_{2}=$ suhu/temperature $70^{\circ} \mathrm{C}$
$\mathrm{T}_{3}=$ waktu/time $240 \mathrm{menit} /$ minute

$\mathrm{S}_{3}=$ suhu/temperature $80^{\circ} \mathrm{C}$

Gambar 9. Nillai EC dalam larutan unsur hara dari ekstrak rumput laut Sargassum sp.

Figure 9. EC value in the nutrient solution extracted from seaweed Sargassum sp. 
berbeda nyata dengan perlakuan $\mathrm{T}_{3} \mathrm{~S}_{2}$, tetapi berbeda nyata dengan perlakuan lain yang diberikan. Nilai EC diperoleh dari banyaknya unsur hara seperti N,P,K $\mathrm{Mg}, \mathrm{Ca}, \mathrm{Mn}, \mathrm{Zn}$ dan B yang terlarut dalam suatu larutan nutrisi tanaman. Semakin pekat suatu larutan nutrisi tanaman semakin banyak unsur hara yang terlarut. Pada penelitian ini jumlah unsur hara yang terlarut dalam larutan $\mathrm{KOH}$ 0,3\% diperoleh pada perlakuan $\mathrm{T}_{3} \mathrm{~S}_{3}$. Menurut Sutiyoso (2003), kandungan EC maksimum untuk sayuran adalah $4,2 \mathrm{mS} / \mathrm{cm}$. Bila angka EC lebih besar maka larutan hara hanya akan lewat begitu saja tanpa diserap oleh akar karena akar sudah "jenuh". Sedangkan menurut Untung (2006) nilai EC sangat penting dalam menentukan produktivitas tanaman. Pada tanaman kecil, angka EC antara 1 $\mathrm{mS} / \mathrm{cm}-1,5 \mathrm{~ms} / \mathrm{cm}$. Kisaran nilai EC dapat ditingkatkan sampai $2,5 \mathrm{~ms} / \mathrm{cm}-4 \mathrm{~ms} / \mathrm{cm}$ menjelang tanaman berbuah/berbunga, kecuali untuk tomat yang EC nya bisa sampai $7 \mathrm{mS} / \mathrm{cm}$. Jika nilai EC lebih dari $4 \mathrm{mS} / \mathrm{cm}$ dapat menimbulkan toksisitas pada tanaman (Sutiyoso, 2003).

Hasil dari analisis EC (Electro Conductivity) sampel ekstrak cair Sargassum sp. dapat diasumsikan bahwa EC dari ekstrak cair Sargassum sp. tergolong baik dan di bawah batas maksimum EC yang telah ditetapkan. Oleh karena itu, ekstrak cair rumput laut Sargassum sp. dapat dimanfaatkan sebagai bahan baku untuk produksi pupuk organik cair.

\section{KESIMPULAN}

Pemberian perlakuan suhu dan waktu ekstraksi yang berbeda berpengaruh signifikan terhadap jumlah larutan unsur hara, viskositas, ALT, phospat, $\mathrm{C}_{\text {Organik' }}$, dan Electro Conductivity cairan ekstrak Sargassum, namun tidak berpengaruh terhadap $\mathrm{pH}$, kadar nitrogen, dan kadar kalium.

Perlakuan terbaik untuk mendapatkan cairan rumput laut Sargassum sp. adalah waktu ekstraksi 240 menit (4 jam) dan suhu ekstraksi $80{ }^{\circ} \mathrm{C}\left(\mathrm{T}_{3} \mathrm{~S}_{3}\right)$ dengan jumlah larutan unsur hara $97,5 \%$; nitrogen 1,64\%;phospat 197,7 ppm; kalium 205,54 ppm; $\mathrm{C}_{\text {Organik }} 0,55 \%$; $\mathrm{C} / \mathrm{N}$ rasio $0,34 \% ; \mathrm{pH}$ 9; viskositas $3,07 \mathrm{cPs} ; \mathrm{ALT} 2,5 \times 10^{3} \mathrm{Cfu} / \mathrm{mL}$; dan EC $3,52 \mathrm{mS} / \mathrm{cm}$.

\section{DAFTAR PUSTAKA}

Anonymous. (2009a). Bahan Organik Perairan. https:// mspuh.wordpress.com/2009/11/21/bahan-organikperairan/. Diakses tanggal 27 Desember 2018.

Anonymous. (2011b). Corganik dan pengapuran. https:/ /nabilussalam.wordpress.com/2011/04/14/corganik-dan-pengapuran/. Diakses tanggal 27 Desember 2018.
Anonymous. (2013c). Effects of Manure and Fertilizer on Soil Fertility and Soil Quality. https://www.gov.mb.ca/ agriculture/environment/nutrient-management/pubs/ effects-of-manure\%20-fertilizer-on\%20soil\%20fertilityquality.pdf. Diakses tanggal 27 Desember 2018.

Anonymous. (2017d). Evaliasi pengaruh pH dan EC pada budidaya tanaman dengan system akuaponik dan hidroponik. https://katasenja.wordpress.com/2017/ $10 / 19 /$ evaluasi-pengaruh-ph-dan-ec-padabudidaya-tanaman-dengan-sistem-akuaponik-danhidroponik/. Diakses tanggal 21 Desember 2017.

Basmal, J. Widanarto, A, Kusumawati. R, dan Utomo B.S.B, (2014). Pemanfaatan limbah ekstraksi alginate dan silase sebagai bahan baku pupuk organik. Jurnal Pascapanen dan Bioteknologi Kelautan dan Perikanan. 9(2), 109-120

Basmal, J., Kusumawati, R., \& Utomo, B. S. B. (2015). Mutu Sap Liquid Rumput Laut Sargassum yang Diekstrak Menggunakan Kalium Hidroksida sebagai Bahan Pupuk. Jurnal Pascapanen dan Bioteknologi Kelautan dan Perikanan, 10(2), 143. https://doi.org/ 10.15578/jpbkp.v10i2.36

Basmal. J., Kusumawati, R., \& Nurhayati. (2016). Penelitian pembuatan pupuk bio padat dan cair dari rumput laut. Laporan Teknis penelitian TA. 2016. Pusat Penelitian dan Pengembangan Daya Saing Produk dan Bioteknologi Kelautan dan Perikanan.

Budiyanto, A. \& Yulianingsih (2008). Pengaruh suhu dan waktu ekstraksi terhadap karakter pektin dari ampas jeruk siam (Citrus nobilis L). J.Pascapanen. 5(2), 3744.

Bulgari, R., Cocetta, G., Trivellini, A., Vernieri, P., \& Ferrante, A. (2015). Biostimulants and crop responses: A review. Biological Agriculture and Horticulture. Taylor and Francis Ltd. https://doi.org/ 10.1080/01448765.2014.964649

Hernández-Carmona, G., McHugh, D. J., \& LópezGutiérrez, F. (1999). Pilot plant scale extraction of alginates from Macrocystis pyrifera. 2. Studies on extraction conditions and methods of separating the alkaline-insoluble residue. Journal of Applied Phycology, 11(6), 493-502. https://doi.org/10.1023/ A:1008114709681

Dalzell, H., Biddelstone, A., Gray, K., \& Thuraniranjan, K. (1987). Soil managment: compost production and use in tropical and subtropical environments. Boletin 56 de Suelos de La FAO, (6.6), 134.

Firdausi, W., \& Zulaika, E. (2015). Potensi Azotobacter spp. sebagai Pendegradasi Lipid dan Protein. Bioeksperimen: Jurnal Penelitian Biologi, 1(2), 18-21.

Grusak, M. A., Broadley, M. R., \& White, P. J. (2016). Plant Macro- and Micronutrient Minerals. In eLS (pp. 1-6). John Wiley \& Sons, Ltd. https://doi.org/10.1002/ 9780470015902.a0001306.pub2

Handayani, H., Sriherfyna, F. H., \& Yunianta. (2016). Ekstraksi Antioksidan Daun Sirsak Metode Ultrasonic Bath (Kajian Rasio Bahan: Pelarut dan Lama Ekstraksi). Jurnal Pangan dan Agroindustri, 4(1), 262-272. 
Handayani, T., Sutarno, T., \& Setyawan, A. D. (2004). Analisis Komposisi Nutrisi Rumput Laut Sargassum crassifolium. J. Agardh. Biofarmasi. 2. 45-52.

Hanafiah, A. L. (2005). Dasar-Dasar Ilmu Tanah.PT. Raja Grafindo Persada Jakarta. 305 hal.

Ibrahim, A. M., Sriherfyna, F. H., \& Yunianta. (2015). Pengaruh Suhu Dan Lama Waktu Ekstraksi terhadap Sifat Kimia dan Fisik Pada Pembuatan Minuman Sari Jahe Merah (Zingiber officinale var. Rubrum) dengan Kombinasi Penambahan Madu sebagai Pemanis. Jurnal Pangan dan Agroindustri, 3(2), 530541.

Jayanudin, Lestari, A. Z., \& Nurbayanti, F. (2014). Pengaruh Suhu dan Rasio Pelarut Ekstraksi terhadap Rendemen dan Viskositas Natrium Alginat dari Rumput Laut Cokelat (Sargassum sp). Jurnal Integrasi Proses, 5(1), 51.

Layek, J., Das, A., Ramkrushna, G. I., Trivedi, K., Yesuraj, D., Chandramohan, M., ... Ghosh, A. (2015). Seaweed sap: a sustainable way to improve productivity of maize in North-East India. International Journal of Environmental Studies, 72(2), 305-315. https:// doi.org/10.1080/00207233.2015.1010855

Muhhamid, (2012). Taksonomi Algae (Ganggang). https:/ /hahmsroom.wordpress.com/2012/10/23/ taksonomi-algae-ganggang/

Mulyanto, B. (2004). Pengelolaan Bahan Organik Tanah untuk Mendukung Kelestarian Pertanian di Lahan Basah. Simposium Nasional ISSAASPertanian Organik. Bogor.

Permentan. (2011). Peraturan Menteri Pertanian Nomor 70/Permentan/SR.140/10/2011. Tentang Pupuk Organik, Pupuk Hayati Dan Pembenah Tanah. Jakarta

Putranto, R. A. (2012). Bioteknologi Tanaman Karet untuk Idonesia. Proceeding Konfrensi Nasonal 2012 di Marseille, I(15). DOI: 10.13140/ RG.2.1.2215.0160. https://www.researchgate.net/ $\begin{array}{llllllllllll}\mathrm{p} & \mathrm{u} & \mathrm{b} & \mathrm{l} & \mathrm{i} & \mathrm{c} & \mathrm{a} & \mathrm{t} & \mathrm{i} & \mathrm{o} & \mathrm{n} & \text { / }\end{array}$ 291348638_Bioteknologi_Tanaman_Karet_untuk_Indonesia Shah, M. T., Zodape, S. T., Chaudhary, D. R., Eswaran, K., \& Chikara, J. (2013). Seaweed Sap As An Alternative Liquid Fertilizer For Yield And Quality Improvement of Wheat. Journal of Plant Nutrition, 36(2), 192-200. https://doi.org/10.1080/ 01904167.2012 .737886

SNI. 01-2354.4-2006 BSN (2006). Cara uji kimia-Bagian 4. Penentuan kadar protein dengan metode total nitrogen pada produk perikanan.

Situngkir. J., (2017). Pembuatan dan karakterisasi Fisikokimia Bahan Cetak Gigi Palsu Kalsium Alginat. Researchgate. www.researchgate.net

SNI, (2004). SNI 06-6989.11-2004. Air dan air limbahBagian 11: Cara uji derajat keasaman $(\mathrm{pH})$ dengan menggunakan alat $\mathrm{pH}$ meter

SNI, (2016). SNI 01-2332-3-2006. Cara uji mikrobiologi -Bagian 3: Penentuan angka lempeng total (ALT) pada prodik perikanan.

Subaryono, S., \& Apriani, S. N. K. (2010). Pengaruh Dekantasi Filtrat pada Proses Ekstraksi Alginat dari Sargassum sp. terhadap Mutu Produk yang Dihasilkan. Jurnal Pascapanen dan Bioteknologi Kelautan dan Perikanan, 5(2), 165. https://doi.org/ 10.15578/jpbkp.v5i2.420

Sutiyoso, Y. (2003). Meramu pupuk hidroponik. Swadaya press, Jakarta.

Widanarto. A. (2013). Pemanfaatan silase limbah kepala ikan kuniran (Uphuneus Sulphureus) dan limbah alginate dari rumput laut coklat (Sargassum sp) sebagai pupuk organik. Karya Ilmiah Prakter Akhir. Sekolah Tinggi Perikanan Jakarta. 90.

Winarno, F.G. (1990). Teknologi pengolahan rumput laut. Pustaka Sinar Harapan, Jakarta, 112.

Zodape, S. T. (2001). Seaweeds As a Biofertilizer. Journal of Scientific and Industrial Research, 60(5), 378-382. 